\title{
Social patterns of road accidents to children: some characteristics of vulnerable families
}

\author{
E Maurice Backett, A M Johnston
}

This is the ninth paper in a series of Injury Classic. Our goal is to reprint one such paper in each issue to initiate newcomers to the field of these old, often quoted, and important contributions. As many are difficult to find, it should help all of us to have a copy at hand. Your suggestions about future articles are welcome. Write to the editor with details of your favourite, most quoted paper.

Professor of Social Medicine, University of Aberdeen EM Backett

\section{Social Worker, Queen's University of Belfast \\ AM Johnston \\ This paper first appeared in the British Medical fournal (1959; i: 409-13) and is reprinted with permission.}

This paper presents the results of a comparison of two groups of schoolchildren and their families. One group had had road accidents (which were not fatal) and the other was a control group without a history of road accidents.

\section{The problem}

Accidents of all kinds were second as a cause of death among children not injured or deformed at birth in England and Wales in 1956 (Registrar General, 1957). Road accidents were by far the most important groups, and accounted for one third of the total deaths. In spite of the recent decline in death rates from road accidents in all age groups except the young adult male and the elderly female (Martin, 1957), these accidents to children are now six times as frequent as tuberculosis or pertussis as a cause of death (Registrar General, 1957). They may well be as important as these diseases and poliomyelitis together as a cause of crippling and deformity. Certainly they killed 15 times as many children as poliomyelitis in 1956, and about twice as many as were killed by this disease in our worst epidemic since the war. In striking contrast to poliomyelitis, road accidents to children arouse little popular attention and have stimulated almost no research (British Medical fournal, 1957; Lancet, 1957). A particularly important omission from the literature is an investigation of what Gordon (1949) calls the 'host factors' in road accidents-the characteristics of the drivers and pedestrians who are involved. However, certain groups are well known to be specially vulnerable. For example, the relatively high road accident rates for males are well recognized, as are the special dangers at the extremes of age.

The small boy pedal cyclist and the young adult motorcyclist also carry very high risks. But many more facts than these are necessary before the vulnerable groups are defined clearly enough to focus preventive measures upon them, or even to decide what are the best means to use in prevention. Recent studies have gone some way to achieve this end. They have taken the epidemiology of road accidents to children to a point where the relative risks at ages and for each sex can be defined (Children's Safety Crusade Trust, 1953; Martin, 1957). These figures suggest that for child pedestrians (among whom most road accidents occur) the risks for boys are at all ages higher than for girls. This sex difference is apparent for all road users, and reaches its peak in the young adult, where the sex ratio for all fatal road accidents is as much as 10 to 1 . The risk of road accidents for both sexes increases up to 6 years of age and then begins to decline gradually, to drop sharply after 9 years. Adolescent girls experience far fewer road accidents than adolescent boys, and are among the best 'risks' on the road.

A few aspects of the behaviour of children at and prior to the accident as well as the accident surroundings have been studied in detail, particularly by the Road Research Laboratory of the Department of Scientific and Industrial Research. The types of vehicles involved, the time of day, and the day of the week have also been investigated, and the police of most areas tabulate road accidents to children against a supposed cause. 'Heedlessness of traffic', for example, was given recently as the cause of a huge majority of road accidents to children in England and Wales.

Study of the 'host' characteristics of personality and intelligence of children involved in accidents of all types has presented great difficulties of method, and it is doubtful how much of this material may be applied in the special field of road accidents. However, the findings of Bimbach (1948) and others in the United States suggest that there may be important differences of personality between children who have accidents and those who do not. Their statement that intelligence (a factor more likely to remain constant before and after an accident than personality) is relatively unimportant may be a useful addition to our understanding. Webb (1955) discusses the methods which may be used in investigating psychological and behavioural characteristics of persons involved in accidents. Charles (1954), in emphasizing the importance of education for prevention, points, by implication at least, to some defect of learning which selects certain groups of people as likely to have accidents.

The process of learning how to take reasonable risks on the road has been studied in this country by Cohen et al (1955, 1956) and at the Road Research Laboratory (unpublished). These inquiries, as well as helping to make possible the definition of a potentially 'dangerous' group, suggest methods which could be used in the detailed analysis of both pedestrian and driver behaviour. All these studies have been focused upon the individual; there have been few, other than those of 
Gordon (1949), which have sought to define the family and social characteristics of the groups from which the vulnerable children come and within which most of the learning about how to avoid accidents must be presumed to take place.

\section{Method}

A randomly selected group of schoolchildren between the ages of 5 and 14 who had had pedestrian road accidents was compared with a matched control group for the following personal and family characteristics: (a) family and maternal health; (b) maternal preoccupation-for example, with work outside the home or with other children; (c) family size and age structure; (d) poverty and prosperity of family; (e) protected and unprotected play; (f) crowding; (g) other accidents; (h) intelligence.

In addition, the distributions of accident children and others in Belfast were compared by an independent rating of parental standards and cooperation.

\section{POPULATION}

The Royal Ulster Constabulary provided the names of the last 250 children aged 5-14 years involved in non-fatal road accidents as pedestrians within the Belfast boundary prior to the beginning of the study. This group formed the experimental accident population, and from it a random sample was drawn to give (with an estimated $10 \%$ wastage) approximately 100 accident families.

\section{CONTROL CHILDREN}

Matched control children who had not had road accidents were picked from the records of the school health service so that they shared the same age (to within $1 \frac{1 / 2}{2}$ months ${ }^{\star}$ ), sex, school, and area of living (and therefore major variations in exposure to traffic). Because of the fact that in this city most children go to the nearest school, differences in the area of living were

${ }^{\star}$ On five occasions the age distribution of children in the school was such that a difference in age of 2 months had to be accepted. well controlled, many pairs of children living near to one another in the same street. There were only two children among those investigated who did not go to the nearest school, and. these were being educated privately. Childreno who did not attend schools within the cit boundary, who were at boarding schools or: institutions, or who were suffering chroni $\underset{+}{\stackrel{9}{+}}$ handicap such as blindness or skeletal defecष were omitted from the study. A map chece showed no reason to suppose that distances from home to school were different in the tw\$ groups, nor did any major traffic intersection\$ differentiate between the two groups. Because of the social homogeneity of neighbourhoods in the city, large differences of social class wer $\overrightarrow{\mathrm{e}_{2}}$ ruled out by this method of selection, and because of the rigidly denominational nature of education in Northern Ireland, accident and control children were always of the same religion.

\section{INTERVIEW}

The homes of all accident and control children were visited by a social worker (AMJ), and $\vec{g}$ schedule was completed at interview with the mother. Factual material was later coded 'blind'-that is, without identification of accis dent or control.

\section{Results}

(A) EFFECT OF FAMILY AND MATERNAL

ILLNESS

Reports of illness within the family of the accident or control child were recorded whe the episodes had occurred at or since the tim of the accident. The period involved was, of course, the same for each pair of families an was usually between three and nine months. $A \frac{9}{9}$ it proved impossible to obtain the ages of a members of the households, morbidity rates have not been calculated. However, more illness was reported among the accidenis families than among the controls, and these differences were significant at the $5 \%$ leved (table 1). This was not due to differences of family size between the groups, but could be related to age differences, particularly among the adults. Because of the notorious inaccuracf of reports of recollected illness, more objective evidence was sought. Details of the diagnosis

Table 1 Association with family and maternal health. Percentage ratios of children observed to those expected (on the nid hypothesis), classified according to whether accident or control and presence or absence of proved family illness

\begin{tabular}{|c|c|c|c|c|c|}
\hline \multicolumn{2}{|l|}{ Type of family illness } & \multirow{2}{*}{$\begin{array}{l}\text { Accident } \\
\text { children (\%) }\end{array}$} & \multirow{2}{*}{$\begin{array}{l}\text { Control } \\
\text { children (\%) }\end{array}$} & \multirow{2}{*}{$\begin{array}{l}\text { No of } \\
\text { children }\end{array}$} & \multirow{2}{*}{$\begin{array}{l}\text { Test of significance } \\
\text { between observed } \\
\text { and expected distributions }\end{array}$} \\
\hline Description & Subgroup & & & & \\
\hline $\begin{array}{l}\text { Family illness } \\
\text { (excluding mother) }\end{array}$ & $\begin{array}{l}\text { None reported } \\
\text { Some reported }\end{array}$ & $\begin{array}{r}86.57 \\
126.47\end{array}$ & $\begin{array}{r}113.43 \\
73.53\end{array}$ & $\begin{array}{r}134 \\
68\end{array}$ & \multirow{2}{*}{$\begin{array}{l}\chi^{2}=6.41 \\
\mathrm{df}=1 \\
0.02>p>0.01 \\
\chi^{2}=4.779 \\
\mathrm{df}=1 \\
0.05>p>0.02\end{array}$} \\
\hline $\begin{array}{l}\text { Family illness } \\
\text { (excluding mother } \\
\text { and with index } \\
\text { child under } 9 \text { years) }\end{array}$ & $\begin{array}{l}\text { None or trivial } \\
\text { More serious } \\
\text { illness }\end{array}$ & $\begin{array}{r}88.17 \\
140.74\end{array}$ & $\begin{array}{r}111.83 \\
59.26\end{array}$ & $\begin{array}{l}93 \\
27\end{array}$ & \\
\hline \multirow[t]{2}{*}{$\begin{array}{l}\text { Maternal illness } \\
\text { only }\end{array}$} & $\begin{array}{l}\text { Involving no } \\
\text { hospital treatment }\end{array}$ & 92.94 & 107.06 & 170 & \multirow{2}{*}{$\begin{array}{l}\chi^{2}=4.493 \\
\mathrm{df}=1 \\
0.05>p>0.02\end{array}$} \\
\hline & $\begin{array}{l}\text { Involving hospital } \\
\text { treatment }\end{array}$ & 137.50 & 62.50 & 32 & \\
\hline
\end{tabular}


and the names of the doctors or hospitals involved had been recorded, and all hospital and general practitioner contacts were traced for an equal sized sample from both accident and control families. The expected irregularities of memory were encountered in the two groups, but were no greater in one than in the other. However, though the chances that control mothers had forgotten a family visit to a hospital during recent months were small, the possibility remains as an uncontrolled source of error. It is less likely still that the mothers forgot their own hospitalization, and an analysis of the material based on confirmed hospital contacts distinguishes the accident and control families in the same way (table 1).

In order to see if the seriousness of illnesses reported by the families distinguished between them, all reported diagnoses were divided into two groups, 'trivial' and 'not trivial'. Into the more serious group were placed the following: illnesses resulting in death or hospital inpatient treatment, as well as pleurisy, nervous breakdown, peptic ulcer, 'kidney trouble', Raynaud's disease, tuberculosis, heart failure, meningitis, chorea, blindness, gangrene, fractures, and concussion.

There was an excess of accident children among the families which reported the more serious diagnoses. This trend was not significant for all the families taken together, but was significant at the $5 \%$ level for the younger group-that is, for those with children most directly under parental control (table 1).

\section{(B) MATERNAL PREOCCUPATION}

The presence of a younger sibling in the family, the mother's pregnancy, and work outside the home were recorded as preoccupations at the material time. In addition there were a few families where dependent elderly relatives or some other serious responsibility could be counted a preoccupation likely to deflect maternal attention and care from the accident or control child. The mothers of the accident children were more often preoccupied in these ways than the mothers of the controls (table 2).

\section{(C) FAMILY SIZE AND AGE STRUCTURE}

Variations of sibship size, birth rank, spacing, and age below 15 years within the accident and control families did not distinguish between them.

\section{(D) POVERTY OF FAMILY : DEPENDANT : EARNER RATIO}

Since there were no important differences of social class between the accident and control families, it was hoped that major differences in family finance might be reflected in the ratio of dependants to earners in the household. This ratio was found to distinguish between the accident and control families, there being an excess of accident children in the families with the higher ratios - that is, more dependants per earner (table 3).

\section{(E) ROOM TO PLAY}

Children were classified according to whether there was a garden, yard or playroom at home, use of playgrounds, fields, etc, near by, or no facilities used at all. Almost all children in both groups played sometimes in the streets. Only small differences in facilities were encountered because of the similarity of housing in the various school areas of the city. If a child was either without anywhere to play at home or without local facilities to play, or did not use them if they existed, his play was regarded as 'unprotected'; others were coded as 'protected'. There was a significant excess of accident children both in the 'unprotected' group and among those with the more objectively measured absence of garden, yard, or playroom (table 4).

Table 2 Association with maternal preoccupation. Percentage ratios of children observed to those expected (on the null hypothesis), classified according to whether accident or control and presence or absence of maternal preoccupation at the time of the accident

\begin{tabular}{|c|c|c|c|c|c|}
\hline \multicolumn{2}{|l|}{ Maternal preoccupation } & \multirow{2}{*}{$\begin{array}{l}\text { Accident } \\
\text { children (\%) }\end{array}$} & \multirow{2}{*}{$\begin{array}{l}\text { Control } \\
\text { children (\%) }\end{array}$} & \multirow{2}{*}{$\begin{array}{l}\text { No of } \\
\text { children }\end{array}$} & \multirow{2}{*}{$\begin{array}{l}\text { Test of significant } \\
\text { between observed } \\
\text { and expected distributions }\end{array}$} \\
\hline Description & Subgroup & & & & \\
\hline $\begin{array}{l}\text { Maternal preoccupation } \\
\text { (sibling, pregnant, work, } \\
\text { other) }\end{array}$ & $\begin{array}{l}\text { Not preoccupied } \\
\text { Preoccupied }\end{array}$ & $\begin{array}{r}86.75 \\
109.24\end{array}$ & $\begin{array}{r}113.25 \\
90.66\end{array}$ & $\begin{array}{r}83 \\
119\end{array}$ & $\begin{array}{l}\chi^{2}=2.045 \\
\mathrm{df}=1 \\
0.20>p>0.10\end{array}$ \\
\hline $\begin{array}{l}\text { Maternal preoccupation } \\
\text { (sibling, pregnant, work } \\
\text { other, with index child } \\
\text { under } 9 \text { years) }\end{array}$ & $\begin{array}{l}\text { Not preoccupied } \\
\text { Preoccupied }\end{array}$ & $\begin{array}{r}70.00 \\
115.00\end{array}$ & $\begin{array}{r}130.00 \\
85.00\end{array}$ & $\begin{array}{l}40 \\
80\end{array}$ & $\begin{array}{l}\chi^{2}=4.537 \\
\mathrm{df}=1 \\
0.05>p>0.02\end{array}$ \\
\hline
\end{tabular}

Table 3 Association with family 'poverty'. Percentage ratios of children observed to those expected (on the null hypothesis), classified according to whether accident or control and a measure family proverty

\begin{tabular}{lllllll}
\hline $\begin{array}{lllll}\text { A measure of family poverty } \\
\text { Description }\end{array}$ & Subgroup & & $\begin{array}{l}\text { Accident } \\
\text { children (\%) }\end{array}$ & $\begin{array}{l}\text { Control } \\
\text { children (\%) }\end{array}$ & $\begin{array}{l}\text { No of } \\
\text { children }\end{array}$ & $\begin{array}{l}\text { Test of significant } \\
\text { between observed } \\
\text { and expected distributions }\end{array}$ \\
\hline Ratio of dependents & $1.0-4.0$ & & 87.50 & 112.50 & 128 & $\chi^{2}=6.3948$ \\
to earners in & $4.1-6.0$ & 131.71 & 68.29 & 41 & $0.05>\mathrm{p}>0.02$ \\
household & $6.1+$ & 109.09 & 90.91 & 33 & 0.02 \\
\hline
\end{tabular}


Table 4 Association with play. Percentage ratios of children observed to those expected (on the null hypothesis), classified according to whether accident or control and two measures of protection while playing

\begin{tabular}{|c|c|c|c|c|c|}
\hline \multicolumn{2}{|c|}{$A$ measure of protection while playing } & \multirow{2}{*}{$\begin{array}{l}\text { Accident } \\
\text { children (\%) }\end{array}$} & \multirow{2}{*}{$\begin{array}{l}\text { Control } \\
\text { children (\%) }\end{array}$} & \multirow{2}{*}{$\begin{array}{l}\text { No of } \\
\text { children }\end{array}$} & \multirow{2}{*}{$\begin{array}{l}\text { Test of significance } \\
\text { between observed } \\
\text { and expected distributions- }\end{array}$} \\
\hline Description & Subgroup & & & & \\
\hline $\begin{array}{l}\text { Household with garden, } \\
\text { yard, or playroom }\end{array}$ & $\begin{array}{l}\text { Yes } \\
\text { No }\end{array}$ & $\begin{array}{r}83.61 \\
125.00\end{array}$ & $\begin{array}{r}116.39 \\
75.00\end{array}$ & $\begin{array}{r}122 \\
80\end{array}$ & $\begin{array}{l}\chi^{2}=7.471 \\
\mathrm{df}=1\end{array}$ \\
\hline Play & $\begin{array}{l}\text { Protected } \\
\text { Unprotected }\end{array}$ & $\begin{array}{r}71.79 \\
117.74\end{array}$ & $\begin{array}{r}128.21 \\
82.26\end{array}$ & $\begin{array}{r}78 \\
124\end{array}$ & $\begin{array}{l}\chi^{2}=9.210 \\
\mathrm{df}=1 \\
0.01>p>0.001\end{array}$ \\
\hline
\end{tabular}

Table 5 Association with crowding. Percentage ratios of children observed to those expected (on the null hypothesis), classifief according to whether accident or control and a measure of crowding

\begin{tabular}{|c|c|c|c|c|c|}
\hline \multicolumn{2}{|l|}{$A$ measure of crowding } & \multirow{2}{*}{$\begin{array}{l}\text { Accident } \\
\text { children (\%) }\end{array}$} & \multirow{2}{*}{$\begin{array}{l}\text { Control } \\
\text { children (\%) }\end{array}$} & \multirow{2}{*}{$\begin{array}{l}\text { No of } \\
\text { children }\end{array}$} & \multirow{2}{*}{$\begin{array}{l}\text { Test of significance } \\
\text { between observed } \\
\text { and expected distributions }\end{array}$} \\
\hline Description & Subgroup & & & & \\
\hline $\begin{array}{l}\text { Persons per bedroom } \\
\text { Persons per bedroom } \\
\text { (adults and older } \\
\text { children constant and } \\
\text { index child under } 11 \\
\text { years) }\end{array}$ & $\begin{array}{l}<1.6 \\
1.6- \\
2.5 \\
<1.6 \\
1.6 \text { or more }\end{array}$ & $\begin{array}{r}75.00 \\
109.33 \\
103.45 \\
69.90 \\
107.73\end{array}$ & $\begin{array}{r}125.00 \\
90.67 \\
86.55 \\
130.70 \\
92.31\end{array}$ & $\begin{array}{r}40 \\
75 \\
87 \\
34 \\
134\end{array}$ & $\begin{array}{l}\chi^{2}=3.257 \\
\mathrm{df}=2 \\
0.20>p>0.10 \\
\chi^{2}=3.938 \\
\mathrm{df}=1 \\
0.05>p>0.02\end{array}$ \\
\hline
\end{tabular}

Table 6 Rating of schools by school medical officers for maternal care and cooperation

\begin{tabular}{|c|c|c|c|c|c|c|}
\hline & \multicolumn{6}{|c|}{ Percentage and No of children in schools with ratings* } \\
\hline & 1 & $2+$ & 2 & $2-$ & 3 & Total \\
\hline $\begin{array}{l}\text { Children in all city schools } \\
\text { less accident children } \\
\text { Accident children in city } \\
\text { schools }\end{array}$ & $\begin{array}{l}14.35 \% \\
(11,012) \\
4.95 \% \\
(5)\end{array}$ & $\begin{array}{l}27.95 \% \\
(21,441) \\
28.71 \% \\
(29)\end{array}$ & $\begin{array}{l}35.55 \% \\
(27,277) \\
33.66 \% \\
(34)\end{array}$ & $\begin{array}{l}13.43 \% \\
(10,301) \\
18.81 \% \\
(19)\end{array}$ & $\begin{array}{l}8.72 \% \\
(6,689) \\
13.86 \% \\
(14)\end{array}$ & $\begin{array}{c}100.00 \% \\
(76,720) \\
100.00 \% \\
(101)\end{array}$ \\
\hline
\end{tabular}

$\chi^{2}=10.510 . \mathrm{df}=4.0 .05>\mathrm{p}>0.02$.

${ }^{\star}$ For details of ratings scale see footnote.

\section{(F) CROWDING}

Families were grouped, using as an index of crowding the number of persons per bedroom. An excess of accident children was found among the more crowded families (table 5), but this remained insignificant until the number of older children and adults was held constant. The association then became significant for the younger children only.

\section{(G) OTHER ACCIDENTS}

Families were questioned about other accidents to relatives within the household which had occurred at or since the time of the index child's accident. Reports of trivial accidents were then separated from others which could be verified by reference to doctor or hospital, and accident rates were computed for the latter. No significant differences between the two groups were found, though there was a small excess of these more serious accidents (fractures, other motor vehicle accidents, and the like) among the younger members of the accident families.

\section{(H) INTELLIGENCE}

The chief educational psychologist for the city of Belfast undertook to test the intelligence of a group of the accident and control children, but reluctance on the part of some of the parents- particularly of the controls-prevented a successful experiment. Thirty four pairs of accio dent and control children were eventuall subjected to a comprehensive battery of test which had been standardized locally. $N \mathscr{8}$ differences in intellectual ability were foun between the two groups.

\section{Rating of parental standards and cooperation}

School medical officers form opinions on the parental standards and cooperation of parents of the children whom they see in school, and was decided that, rough though they were? these judgments might be relevant to the accident and parental care problem in Belfasto The control series of families was not used in this part of the study, which sought confirmas tion that the accident families came from among the less cooperative groups of parents in the city. Three school medical officers were asked to rate upon a five-point scale* the parental standards and cooperation 'generallsw to be found' in their experience in all the city schools. The final rating given to a school wa: agreed between the three without knowledge off which schools were attended by the accident children. It was found that significantly more accident children than were expected on th $\$$ null hypothesis attended schools rated as having poor standards and cooperation wite the school health service (table 6). This findin $\mathbb{D}$ does not, of course, imply a direct relationship

* Rating 1: The children in this school are generally cleå and well turned out. They are free from vermin. Parente cooperation with the school health service is fair or good.

Rating 2: The children of this school are average in respects which reflect maternal care. Parental cooperation is average.

Rating 3: The children in this school are habitually dirty and badly clothed. They are occasionally infested. Parents do not cooperate and are often negligent. Attendence is irregular.

Ratings $2+$ and $2-$ are intermediate. 
between accidents and what was assessed. Accidents could result, for example, from greater traffic congestion or more dangerous streets in the areas where there were schools given a low rating. However, map checks upon the distribution of schools given different ratings suggesting that this was not the only explanation of the association.

\section{Discussion}

INTERACTION

The family patterns and other factors which are associated with accidents to the children in these studies can hardly be isolated one from another. A very large number of interactions between them is possible-for example, the apparent association between accidents and overcrowding might in reality be due to an association between overcrowding and households without play facilities. Some 40 of these interactions have been examined. A few of the more important positive and negative findings are mentioned in this discussion.

\section{FAMILY AND MATERNAL ILLNESS}

That any illness in a family group (either of the mother or elsewhere in the household) should render a healthy child more vulnerable to road accidents is a hypothesis which it is easy to accept in terms of a falling off in maternal care. Illness rates are unimportant in this situation, for the mother is probably involved whatever the family size and age composition. Standardization of the material supported this notion and suggested that family and maternal illness are relatively isolated factors associated with accidents.

Maternal preoccupation as a factor in the vulnerability of children is also readily understood in terms of care and protection. The interaction of maternal preoccupation and other factors was examined, but the strength of the associations in the younger children was unaffected.

\section{FAMILY SIZE AND AGE}

While there were no significant differences between the accident and control families as regards family size and age, so far as the latter was known, it seems that the family patterns found to be associated with accidents have more effect upon the younger children. Several of the associations observed became statistically significant when only the younger age groups were reviewed-for example, maternal preoccupation. Yet others increased their strength-for example, protected and unprotected play. These findings reinforce the logic of the notion that family patterns have more effect upon the younger than upon the older child and that we must look increasingly outside the family for the factors influencing risk taking in the older child. If it is accepted that risk taking is learned early in life, then there is evidence here that it is in the younger family that a diagnosis of vulnerability is most important.

\section{DEPENDANT: EARNER RATIO}

In the absence of known income and within one social class this ratio should be a fair measure of family resources. However, its use was complicated in this study by some interaction with other factors. Standardization for the number of older children and adults in a family and for protection during play, for example, appreciably reduced the association. Thus it seems unlikely that the dependant: earner ratio is associated with accidents to these children.

\section{PLAY}

The association between accidents and lack of play facilities in the home is unlikely to have been affected by differences in the reliability of reporting. The assessment of 'unprotected' play was not so immune. However, both associations were stronger than with other items and unassailed by standardization. These findings suggest that play facilities and protection are important and relatively independant factors.

\section{OTHER ACCIDENTS}

The small excess of 'serious' accidents found among the young relatives of accident children reinforces the notion that it may be the family rather than the individual who is vulnerable.

The crowding of the family was a significant factor only when the number of older children and adults was held constant. It was unaffected by other standardizations, which suggests that it is relatively independent as a factor associated with accidents.

Intelligence differences were not demonstrated between the small number of accident and control pairs who were tested. In spite of these small numbers it was to be expected that suggestive differences would have been observed had the two groups differed in this respect.

Parental standards and cooperation: Care or negligence in the training of children for safe risk-taking may well be linked to the local 'norm' of family care; but this association remains to be demonstrated, as does the existence of such local 'norms'.

\section{Conclusions and summary}

In the investigation of some of the newer health problems-of which road accidents is an example - there is a need for studies which lie between the large scale epidemiological survey and the small sociological inquiry. Such family studies are likely to find a place in the investigation of associations between ill health and personal habits, diet, maternal care, leisure pursuits, etc. For a variety of reasons they must rely upon the use of unsophisticated measures and techniques, and are thus only a prelude to further and more methodologically exact social-medical injury. Their findings often serve merely to confirm what might be guessed at by any reasonable observer. This study of 101 families in which a healthy child has survived a 
road accident suggests that their vulnerability was associated with one or more of the following characteristics (shown significantly less often by a matched control series): there was illness, either maternal or elsewhere in the household, and more serious illness; there was maternal preoccupation of some kind-for example, with outside work, with other children, or with pregnancy. The vulnerable family was more crowded, and it did not provide protection during play or even elementary play facilities.

Overlapping of these factors was small in amount and family and maternal illness, preoccupation of mother, play facilities, and protection during play appear to be independent and important. Crowding (though significantly associated with accidents) appeared less important and less likely than other factors to be directly associated with accidents. Sibship size, birth rank, spacing, and age structure of family did not distinguish significantly between accident and control, nor did the intelligence of the index child or a history of other accidents in the family. The associations described were stronger with the younger index children. A rating of local schools suggested that accident children are to be found more often than might be expected among schools where parental standards are said to be generally rather low.

We are grateful to Dr Leonard Walby, school medical officer to the city of Belfast, for his active help and encouragement, and his assistants. We thank Dr WG Swann, medical officer health, Professor AC Stevenson and Dr EA Cheeseman their help and advice. Mr JD Merritt, Mr S Crockett, and Miss Cooper undertook much of the computing, and Miss P Stewar and Miss H Cogger the typing. We are grateful to them to other colleagues in Queen's University and the London School colleagues in Queen's University and the London School Hygiene. We are especially grateful to the Royal Ulster Constabulary and to Division Inspector NH Sweny for help on drawing the sample of accident children. We also thank 19 Harrison, formerly educational psychologist to the Belfast Education Committee, for measuring the intelligence of tor sample of children. and accident free pupils. Thesis No 1124, New York University. Br Med f 1957; 1, 753.

Charles J (1954). Practitioner 172, 613 .

Children's Safety Crusade Trust (1953). The child on the rod? Economic Research Council, London.

Cohen J, Dearnaley EJ, Hansel CEM (1955). Operat Res Quart $6,3$.

Cohen J, Dearnaley EJ, Hansel CEM (1956). Ibid 7, 67.

Gordon JE (1949). Am $\mathcal{F}$ Public Health 39, 504.

Gordon JE (1957). Lancet 2, 990.

Martin WJ (1957). Brit $\mathcal{F}$ Prev Soc Med 11, 90.

Registrar General (1957). Statistical review of England and Wale for the year 1956. Part I, Tables, Medical, HMSO. London.

Webb WB (1955). Public Health Rep (Wash). 70, 951.

\section{Editorial Board Member: brief biography}

\section{ELENI PETRIDOU}

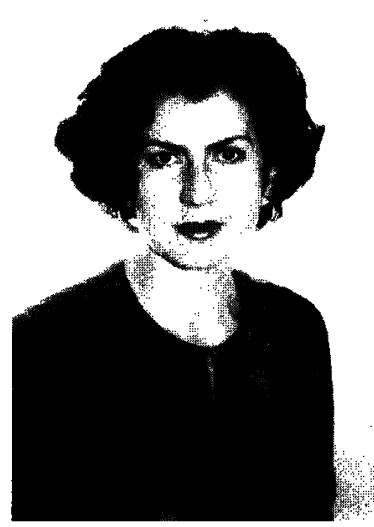

Eleni Petridou is a graduate of the medical school of the University of Athens, and a licensed pediatrician and social medicine specialist. She holds a Master of Public Health degree from the Harvard School of Public Health, and a Doctorate in Hygiene and Epidemiology from the University of Athens. Currently, Eleni is an Assistant Professor at the Athens University Medical School and holds visiting appointments in the Departments of Epidemiology and Maternal and Child Health at the Harvard School of Public Health.

Dr Petridou has an extensive expertise in pediatric and perinatal epidemiology, in particular, in childhood leukemia and the nutritional etiology of childhood disorders. However, her main focus of research is childhood injuries and their prevention. She is Director of the National Center for Research and Prevention of Injuries Among the Young (CEREPRI), President of the Hellenic Society for Social Pediatrics and Health Promotion, Past President of the European Society for Social Pediatrics (ESSOP) and member of several international bodies in matters related to prevention of injuries and health promotion. She has published more than 50 research papers in the international literature and has received numerous distinctions and awards. 